\title{
Indigenous knowledge of the people in Karya Usaha Hamlet (Kubu Raya, West Kalimantan, Indonesia) on the processing and diversity of plants that enhance toddler's appetite
}

\author{
RUQIAH GANDA PUTRI PANJAITAN ${ }^{1, \bullet}$, MITALIA ${ }^{1}$, RUHYAT PARTASASMITA ${ }^{2, v \vee}$ \\ ${ }^{1}$ Biology Education Program, Faculty of Teacher Training and Education, Universitas Tanjungpura. Jl. Prof. Hadari Nawawi, Pontianak 78124, West \\ Kalimantan, Indonesia. Tel.: +62-561-739630, "email: ruqiah.gpp@ fkip.untan.ac.id \\ ${ }^{2}$ Department of Biology, Faculty of Mathematics and Natural Sciences, Universitas Padjadjaran. J1. Raya Bandung-Sumedang Km. 21, Jatinangor, \\ West Java, Indonesia. Tel.: +62-22-84288888, "email: rp2010rikkyo@gmail.com, ruhyat.partasasmita@unpad.ac.id
}

Manuscript received: 25 May 2020. Revision accepted: 25 August 2020.

\begin{abstract}
Panjaitan RGP, Mitalia, Partasasmita R. 2020. Indigenous knowledge of the people in Karya Usaha Hamlet (Kubu Raya, West Kalimantan, Indonesia) on the processing and diversity of plants that enhance toddler's appetite. Biodiversitas 21: 4284-4290. Traditional medicines derived from plants are widely consumed daily by the people of Karya Usaha Hamlet in Indonesia. Not only it is used by adults but also children under the age of five, to increase their appetites. This information was the key to a scientific assessment as it was an effort for health resilience in the community. Therefore, this study aimed to understand the diversity of plant species that is prospective to enhance the toddler's appetite and its process. The method used in this study was a qualitative analysis using a semistructured interview technique with several informants, which consisted of midwives, health service workers, Posyandu cadres, and people from the ethnic origin. The parts of the plants used as traditional medicinal ingredients were subjected to a qualitative phytochemical screening. The results revealed that seven species were potential as appetite enhancers for toddlers. Furthermore, sixty percent of the informants exhibited Javanese turmeric (Curcuma xanthorrhiza Roxb.) mainly as herbal medicine, while $25.8 \%$ and $14.2 \%$ chose the fingerroot (Boesenbergia pandurata (Roxb.) Schlecht.) and common turmeric (Curcuma domestica L.), respectively, as main herbal medicine. On the other hand, flavor enhancers on food from the diversity of plants used mostly by midwives in the village were on average of 2.19 species. Medicinal plants were generally processed by boiling and further adding honey or sugar so that children under the age of five will have a sweet flavor as they drink it.
\end{abstract}

Keywords: Borneo, nutritious plants, toddler appetite

\section{INTRODUCTION}

The ethnic diversity on the island of Borneo is very high, which is relevant to the variety of culture and social life. For instance, in the Karya Usaha Hamlet, Kuala Mandor A Village, Kuala Mandor B Sub-district, seven ethnic groups belong to these places, but the most one is Madurese. This diversity upsurges the cultural variety, especially in utilizing the existing natural resources on the island of Borneo. One of these natural resources that are often used is strictly related to plants that are commonly used in traditional medicine. Public knowledge of various benefits of the plants in medication is gained from generation to generation from their ancestors (Noorcahyati 2012). Karya Usaha Hamlet community regularly applies several plants in various activities, including death ceremonies, marriage events, nugal (rice planting) rituals, rice harvest parties, tolak bala rituals (feeding villages), and seven-month pregnancy parties or baby shower events. Not only that, but Karya Usaha Hamlet community also holds such traditions related to healthy, by establishing plants as medicine. Although health facilities exist, this has no effect on the role of plants as medicine because the community still adheres to tradition and considers that traditional medicine is cheap and easy to obtain.
In general, Indonesia's local people use medicinal plants as herbal ingredients for various diseases. Such ethnics are identified in East Kalimantan (Wibisono and Azham 2017), in the Aceh Pidie community (Saudah et al. 2019), Karo sub-ethnic Batak in North Sumatra (Silalahi and Nisyawati 2018), in the Kaili Rai people of Central Sulawesi (Zubair et al. 2019), local communities in Kupang District, East Nusa Tenggara (Ledo and Seran 2019), Dani ethnic, Papua (Mabel et al. 2016), surrounding communities on Mount Ungaran, Central Java (Utami et al. 2019), and the Cibunar Community and Karangwangi Community, West Java (Iskandar et al. 2004). In the Karya Usaha Hamlet community, people apply medicinal plants in addition to treating diseases, as well as supplements to increase toddler's appetite. However, in other local communities, plants are used as food supplements with respect for fitness and strength of men (Iskandar et al. 2004; Vyas et al. 2014; Marandi and Britto 2015; Mabel et al. 2016; Saudah et al. 2019; Kumar and Saikia 2020; Thakur et al. 2020; Thomas et al. 2020). Providing supplements to increase toddler's appetite is necessary, so they can eat more foods which result in rapid and healthy body growth and avoiding stunting.

Appetite is a condition that drives a person to satisfy his bodily desire to eat more rather than being hungry (Boquin et al. 2014; Tharner et al. 2014; Cardona et al. 2015; Horst 
et al. 2016). Appetite is influenced by palatability (Sørensen et al. 2003). An individual can experience an appetite disorder due to several factors that might be decreasing the desire (Limananti and Triratnawati 2003). Appetite disorders occur as a result of an illness leading to the decline of a person's appetite (Klein and Walsh 2004). Also, the provision of sugary diets close to mealtime can cause a decrease in taste due to full of stomach.

Appetite disorders can be a severe problem, especially in toddlers, because they need more energy and nutrition for their growth (growth and Limananti and Triratnawati 2003; Cowbrough 2010; Horst et al. 2016; Brown et al. 2016; Northstone and Emmett 2013). If a toddler experiences an appetite disorder, there will be an imbalance in nutrient intake, which causes the toddler's development process to be hampered because inadequate absorption of nutrients happens since the absorption of nutrients is a significan tissue in their physical growth and intelligence development (Cowbrough 2010). Nutrient intake, such as carbohydrates, needs to be balanced for optimal child growth (Cofnas 2019; Hulett et al. 2014). Besides, nutritional upbringing, energy, and protein consumption levels are also factors in influencing food consumption that will directly determine the nutritional status of children under the age of five (Cofnas 2019; Melina et al. 2016). Nutrients are food substances that provide energy, and are needed for growth, development, or maintenance of health, as well as reproduction. Nutrients consist of carbohydrates, proteins, fats, vitamins, minerals, and water, which can be obtained from food and drinks (BPOM 2014).

Many efforts are performed by parents to fulfill their toddler's nutritional needs in order to increase their children's appetite. These efforts may be made in one way by using traditional medicinal plants. Natural ingredients used to improve appetite generally work by stimulating bile production. The further report claimed that the work process of appetite-enhancing drugs on children is to boost metabolism, suppress or inhibit gastric acid, and stimulate food secretion, including the bodily desire of an appetite (Limananti and Triratnawati 2003). In connection with that, the objective of this research was to inventory the types of plants to increase appetite for toddlers in Karya Usaha Hamlet and to conduct a phytochemical screening of their metabolite contents.

\section{MATERIALS AND METHODS}

\section{Research sites}

Karya Usaha Hamlet is one of the four hamlets (subvillages) located in Kuala Mandor A Village, Kuala Mandor B Sub-district, Kubu Raya District, West Kalimantan Province, Indonesia (Figure 1). The ethnic groups inhabiting the Karya Usaha Hamlet are the Madurese, the Dayak, the Malays, the Javanese, the Bugis, and the Chinese. However, the most dominant one is the Madurese. The primary source of livelihood of the population is farming. Health services, at present, have been handled by one paramedic and one nurse at the auxiliary health center, the distance of this center to the village is about $\pm 10 \mathrm{~km}$.

Based on Statistics of Kuala Mandor A Village (2019), in 2019, the total area was 11,205.02 ha, consisting of Karya Usaha Hamlet (1,555.06 ha), Karya Bersama subvillage (1,384.21 ha), Bakti sub-village (3,289.45 ha), and the True village (4,976,3 ha). The total population of Karya Usaha Hamlet was recorded by 2,790 people, who came from 476 households. The main occupation of Karya Usaha Hamlet people is a farmer. The agroecosystem is devoted to a home-garden, wet-rice fields, and garden/mixed garden system. The home-garden is an integrated land-use system on which a house is built. It usually consists of a mixture of annual and perennial crops and wild animals (Figure 2).
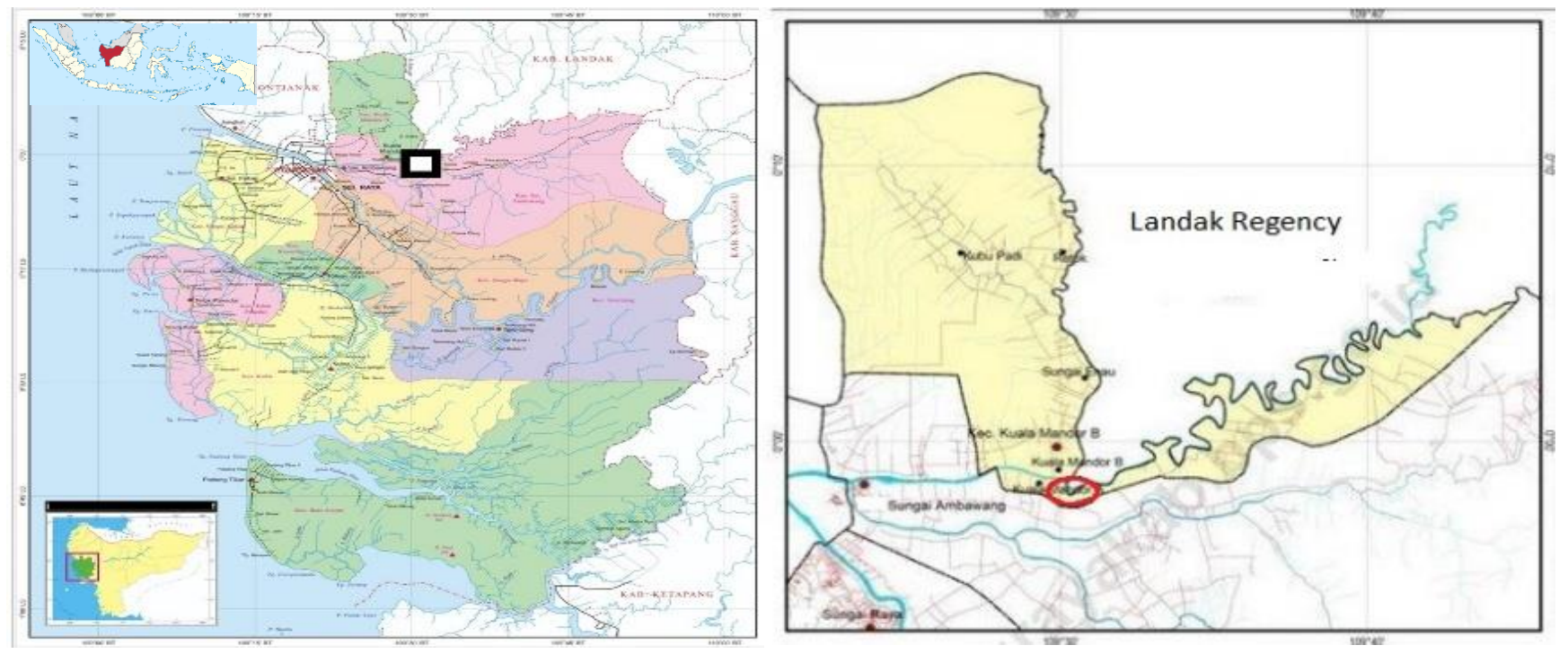

Figure 1. Map of Karya Usaha Hamlet, Kuala Mandor A Village, Kuala Mandor B Sub-district, Kubu Raya District, West Kalimantan Province, Indonesia ()$_{0}$ 


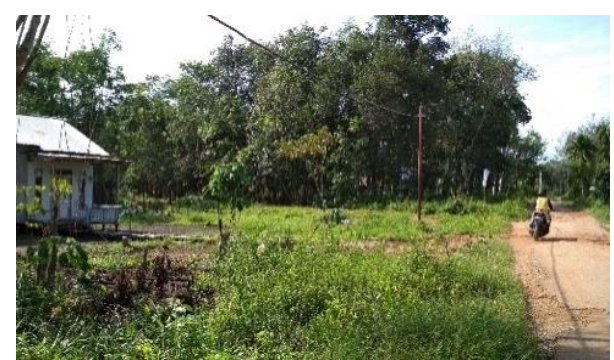

A

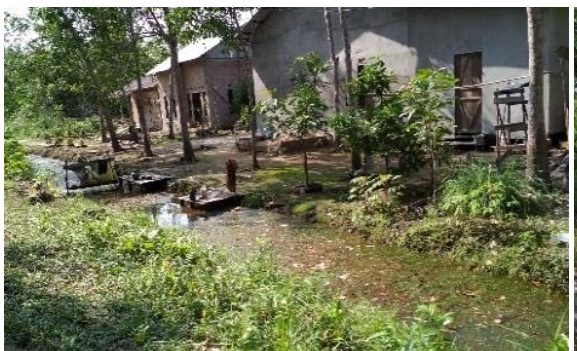

B

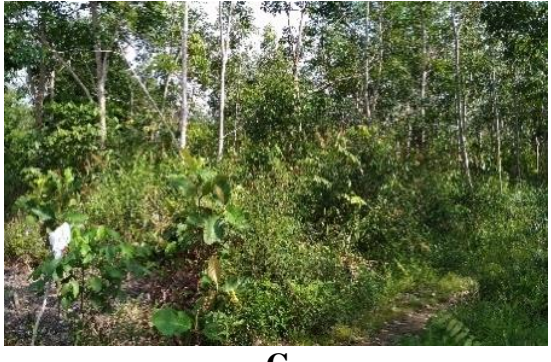

C

Figure 2. A-B. Home-garden system of Karya Usaha Hamlet, Kubu Raya, Indonesia that is predominantly planted by perennial plants, C. Agroforestry (mixed annual and perennial plants)

\section{Procedures}

The method used in this research was qualitative analysis (Creswell 1994). This method is the approach of medical ethnobiology and ethnobotany applied by Ferreira et al. (2014), and Albuquerque et al. (2014). Some field techniques, such as observation, semi-structured interviews, and recording medical plant species in the home-garden system, were applied in this study. Purposive sampling technique was used to select informants who were considered to have understood the traditions of traditional medicine and to have used the plants as medicines, primarily for enhancing toddlers' appetite. The selected informants were 21 people consisting of five men and seven women. Twenty-one were chosen as informants included one village midwife, one health official, one Integrated Healthcare Center (Posyandu) cadre, 18 residents of Karya Usaha Hamlet representing the ethnic groups, namely Buginese, Dayaks, Javanese, Malays, Madurese, and Chinese.

Data collection used a triangulation method with observation, interview, and documentation techniques. Observations were made based on the information of informants related to the location of the study for sampling and the use of plants as a traditional appetite enhancer for toddlers by the Karya Usaha Hamlet community. Interviews were conducted with structured interview techniques. Next, the collection of plant samples was made for aiming for an herbarium. Plant species identification was carried out using the flora book for schools in Indonesia from Van Steenis (2008) and a book of plant morphology from Tjitrosoepomo (2009).

Qualitative phytochemical screening was performed at the Laboratory of Faculty and Mathematics and Natural Sciences, Tanjungpura University, Pontianak, Indonesia. Phytochemical-tested parts of the plants were qualitatively adjusted to the objective of this study as an appetite enhancer in toddlers. Plant samples consisting of leaves and rhizomes were cleanse using tap water, then were cut into small pieces and drained. Samples were weighed using analytical balance to determine the wet weight of the sample. The drying process of the samples was conducted with the help of sunlight (Muthmainnah 2016). Samples were confirmed dried when the weight of the sample was constant (Harborne 1987). Generally, plant leaves contain up to $90 \%$ water. The dried leaves were considered dried if the remaining water content in the leaf sample was about $10 \%$. The rhizome was claimed as a completely dried if the water content in the sample was merely $8-10 \%$. Samples that had been dried were mashed by blender to obtain dry powder (Muthmainnah 2016). $100 \mathrm{~g}$ of the powder samples were isolated for extraction materials. Extraction was carried out by maceration at room temperature for $3 \times 24 \mathrm{~h}$ using a technic of distilled ethanol $96 \%$ submerged. The thick extract was obtained by concentrating the filtrate using an evaporator at $\pm 40^{\circ} \mathrm{C}$. The concentrated results were stored in vial bottles. The qualitative phytochemical screening included the tests of alkaloid, flavonoid, condensed tannin, phenol, steroid, terpenoid, saponin, and glycoside that referred to the Harborne (1987) procedure. The entire data of the results, both the type of plants and the plant's parts, were used. The processing of the selected plants as an appetite enhancer for toddlers and the results of the phytochemical analysis were analyzed descriptively.

\section{RESULTS AND DISCUSSION}

\section{Results}

Based on the information from various informants, it is concluded that the types of plants used by the people of Karya Usaha Hamlet as an appetite enhancer for toddlers were seven species, namely (A) galangal (Kaempferia galanga L.), (B) turmeric (Curcuma domestica L.), (C) Javanese turmeric (Curcuma xanthorrhiza Roxb.), (D) fingerroot (Boesenbergia pandurata (Roxb.) Schlecht.), (E) red ginger (Zingiber officinale Rosc.), (F) aeruginous turmeric (Curcuma aeruginosa Roxb.) (G) papaya (Carica papaya L.) (Table 1, Figure 3 ).

The results of the qualitative phytochemical tests revealed that the plants contained various classes of compounds (Table 2).

The results of this qualitative phytochemical test were reported in letter No. 036 / LABKIM / XI / 2017 (Table 2). The processing methods of these plants as a toddler's appetite enhancer were presented in Table 3. 
Table 1. Utilization of toddler's appetite-enhancing plants by the Karya Usaha Hamlet, Kubu Raya, Indonesia community

\begin{tabular}{|c|c|c|c|c|c|c|c|}
\hline \multirow{2}{*}{$\begin{array}{l}\text { Infor- } \\
\text { mant } \\
\text { code }\end{array}$} & \multirow{2}{*}{$\begin{array}{l}\text { Position of } \\
\text { informant }\end{array}$} & \multicolumn{6}{|c|}{ Plant names } \\
\hline & & $\mathbf{A}$ & $\mathbf{C}$ & D & $\mathbf{E}$ & $\mathbf{F}$ & $\mathbf{G}$ \\
\hline 01 & Village midwife & + & + & & + & & + \\
\hline 02 & Posyandu cadres & & + & & & + & \\
\hline 03 & Bugis tribal rep. & + & + & & & & \\
\hline 04 & Bugis tribal rep. & + & & & + & + & \\
\hline 05 & Bugis tribal rep. & & + & + & & & \\
\hline 06 & Dayak tribal rep. & + & + & & & & \\
\hline 07 & Dayak tribal rep. & & + & & & & + \\
\hline 08 & Chinese ethnic rep. & + & + & & & + & \\
\hline 09 & Madura tribal rep. & + & + & & & & + \\
\hline 10 & Madura tribal rep. & + & + & & & & + \\
\hline 11 & Madura tribal rep. & & + & & & & + \\
\hline 12 & Madura tribal rep. & & & & + & & + \\
\hline 13 & Madura tribal rep. & + & + & & & & + \\
\hline 14 & Madura tribal rep. & & & + & & + & \\
\hline 15 & Javanese ethnic rep. & & + & & & & + \\
\hline 16 & Javanese ethnic rep. & & + & & & & + \\
\hline 17 & Malay ethnic rep. & + & + & & & & \\
\hline 18 & Malay ethnic rep. & & + & & & & \\
\hline 19 & Malay ethnic rep. & + & & & & + & \\
\hline 20 & Malay ethnic rep. & & & + & + & & \\
\hline 21 & Health official (midwife) & & + & & & & + \\
\hline Total & & $7 \quad 3$ & $3 \quad 14$ & 3 & 4 & 5 & 10 \\
\hline $\begin{array}{l}\text { Note: } \\
\text { (Curcu } \\
\text { xanthor } \\
\text { (Roxb.) } \\
\text { Aerugi } \\
\text { (Carice }\end{array}$ & $\begin{array}{l}\text { A. Galangal (Kaempferi } \\
\text { na domestica L.), C. } \\
\text { rhiza Roxb.), D. Finger } \\
\text { Schlecht.), E. Red ginge } \\
\text { ous turmeric (Curcuma } \\
\text { papaya } \text { L.). rep.: represen }\end{array}$ & $\begin{array}{l}\text { a galc } \\
\text { Javane } \\
\text { root }( \\
\text { r (Zing } \\
\text { aerugil }\end{array}$ & $\begin{array}{l}\text { langa } \\
\text { lese tu } \\
\text { (Boesen } \\
\text { giber o } \\
\text { inosa } \mathrm{R}\end{array}$ & & & & \\
\hline
\end{tabular}

\section{Discussion}

The plants that were used as an appetite enhancer for toddlers by Karya Usaha Hamlet were those commonly found in daily life. The community could easily discover them because they grew in the yard of the house, in the garden, or on the roadside. Plant species most frequently used by various ethnic groups were Javanese turmeric (Curcuma xanthorrhiza Roxb.), while the least used were turmeric (Curcuma domestica L.) and fingerroot (Boesenbergia pandurata (Roxb.) Schlecht.) (Table 1). The diversity of plants used as food enhancers consisted of an average of 2.19 species, with the most dominant and least of plants used by village midwives (Table 1). The high diversity of plant species used by them was likely due to the high demand for advice concerning childcare, especially while checking up the children at the Posyandu. Likewise, due to the high frequency of consultation in terms of treating patients by village midwives, the environment near the house (in the home-garden) contained many plants, a variety of medicinal plants.

The role of Javanese turmeric, aeruginous turmeric, and papaya leaves to increase appetite played through the stimulation of enzymes so that the stomach would have the feeling of emptiness then the signals were transmitted to the brain, which urged eating desire arising. Furthermore, ginger was also believed to work to stimulate the production of bile so that appetite actively arose in a person. Papaya leaves and aeruginous turmeric were reported to contain bitter substances (carpaine or bitter alkaloids), which stimulated the child's stomach to function appropriately (Limananti and Triratnawati 2003). Besides, turmeric was efficacious to stimulate bile secretion so that it might launch the process of fat digestion (Niranjan and Prakash 2008).

Table 2. The contents of secondary metabolites of plants which act as an appetite enhancer

\begin{tabular}{|c|c|c|}
\hline $\begin{array}{l}\text { Scientific } \\
\text { name }\end{array}$ & Part used & $\begin{array}{l}\text { The content of secondary } \\
\text { metabolites }\end{array}$ \\
\hline K. galanga & Rhizome & $\begin{array}{l}\text { Alkaloid, flavonoid, saponin, } \\
\text { glycoside }\end{array}$ \\
\hline C. domestica & Rhizome & $\begin{array}{l}\text { Alkaloid, flavonoid, phenol, } \\
\text { terpenoid, glycoside }\end{array}$ \\
\hline C. xanthorrhiza & Rhizome & $\begin{array}{l}\text { Alkaloid, flavonoid, phenol, } \\
\text { terpenoid, glycoside }\end{array}$ \\
\hline B. pandurata & Rhizome & $\begin{array}{l}\text { Alkaloid, flavonoid, phenol, } \\
\text { saponin }\end{array}$ \\
\hline C. papaya & Young leaves & $\begin{array}{l}\text { Alkaloid, phenol, steroid, } \\
\text { saponin, glycoside }\end{array}$ \\
\hline $\begin{array}{l}\text { Z. officinale } \\
\text { (red ginger) }\end{array}$ & Rhizome & Alkaloid, flavonoid, phenol \\
\hline C. aeruginosa & Rhizome & $\begin{array}{l}\text { Alkaloid, phenol, terpenoid, } \\
\text { saponin }\end{array}$ \\
\hline
\end{tabular}

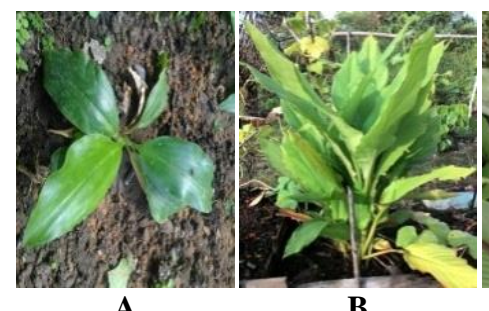

A

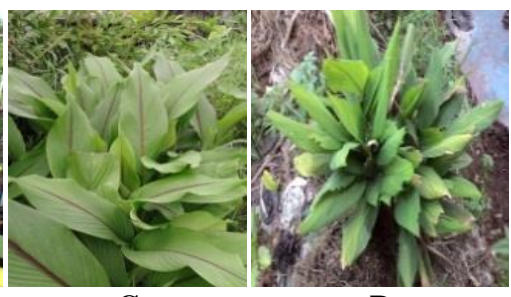

C
D

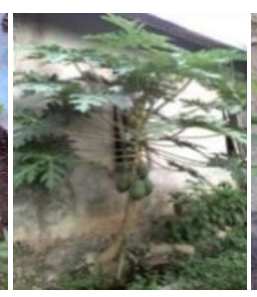

$\mathbf{E}$

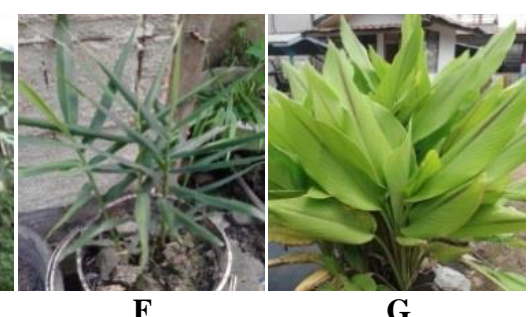

G

Figure 3. Type of plants for enhancing toddler's appetite from the results of an inventory of plants in Karya Usaha Hamlet, Kubu Raya, Indonesia: A. Galangal (Kaempferia galanga L.), B. Turmeric (Curcuma domestica L.), C. Javanese turmeric (Curcuma xanthorrhiza Roxb.), D. Fingerroot (Boesenbergia pandurata (Roxb.) Schlecht.), E. Red ginger (Zingiber officinaleRosc.), F. Aeruginous turmeric (Curcuma aeruginosa Roxb.), G. Papaya (Carica papaya L.) 
Table 3. Methods for processing toddlers' appetite-enhancing plants by the Karya Usaha Hamlet, Kubu Raya, Indonesia community

\begin{tabular}{|c|c|c|}
\hline Local \& scientific name & $\begin{array}{l}\text { Part } \\
\text { used }\end{array}$ & Processing method \\
\hline $\begin{array}{l}\text { Kencur } \\
(\text { Kaempferia galanga } \mathrm{L})\end{array}$ & Rhizome & $\begin{array}{l}\text { Five kencur of rhizome segments were crushed and boiled into } 2 \text { cups }(0.47 \text { liters }) \text { of } \\
\text { water, then } 1 / 2 \text { segment of sliced ginger rhizome was added and removed then filtered, } \\
\text { next } 1 / 4 \text { teaspoon of salt and } 1 \text { tablespoon of sugar was added and cooled, finally, the } \\
\text { concoction was given to the children. } \\
\text { Five to ten kencur of rhizome segments were crushed and boiled into two cups of water, } \\
\text { then were removed and filtered; added one tablespoon of honey or } 1 / 2 \text { tablespoon of } \\
\text { sugar eventually, cooled, and the concoction was given to the children. }\end{array}$ \\
\hline
\end{tabular}

Kunyit

(Curcuma domestica $\mathrm{L}$.)

Temulawak

(Curcuma xanthorrhiza Roxb.)

Temu kunci

(Boesenbergia pandurata

(Roxb.) Schlecht)

Jahe merah

(Zingiber officinale Rosc.)

Temu ireng

(Curcuma aeruginosa Roxb.)

Rhizome

Rhizome

Rhizome

One to two turmeric of rhizome segments were crushed and then boiled intol glass of water, and 5 slices of kencur were added, then removed, filtered, and cooled, next the concoction was given to the children.

Rhizome One ginger of rhizome segment was grated and boiled into 2 cups ( 0.47 liters) of water, then removed and filtered; 1 tablespoon of honey or $1 / 2$ tablespoon of sugar was added, then cooled and the concoction was given to the children.

One grated segment rhizome was squeezed into the water, added the teaspoon of salt and $1 / 2$ tablespoon of sugar, and the concoction was given to the children.

Five segments of rhizome were crushed and boiled into 2 cups ( 0.47 liters) of water, then were removed and filtered; then 1 tablespoon of honey or 1 tablespoon of sugar was added and cooled then the concoction was given to the children.

Rhizome

One segment of red ginger root was crushed and boiled into1 glass of water, then removed and filtered, then $1 / 2$ tablespoon of sugar or 1 tablespoon of honey was added and cooled, then the concoction was given to the children.

One segment of red ginger root was grounded and brewed intol glass of warm water and was added with 1 tablespoon of sugar, allowed to be cooled down and filtered, then the concoction was given to the children.

water and was added with $1 / 4$ teaspoon of salt, then removed, filtered, and cooled down, then the concoction was given to the children.

One to three segments of the shredded black rhizome were squeezed into the water, then were added with $1 / 4$ teaspoon of salt and $1 / 2$ tablespoon of sugar, then the concoction was given to the children.

Pepaya

(Carica papaya L.)

Young

One to two pieces of young papaya leaves were crushed and squeezed into the water, then were added with 3 tablespoons of honey or 1 tablespoon of sugar and the concoction was given to the children.
In connection with the emergence of appetite, Sørensen et al. (2003) stated that the hypothalamus plays the process of regulating the balance of energy in the body through three interrelated processes. The process includes controlling hunger and satiety, regulating the rate of energy expenditure, and regulation of hormone secretion. The process of regulating energy storage occurs through signals centered on the hypothalamus. These signals can be divided into short and long signals. These signals are anabolic, which increases hunger and decreases energy expenditure and catabolic, namely anorexia, and also increases energy outflow. The short signal will affect meal portions and mealtimes and is related to gastric and gastrointestinal peptide distention factors played by cholecystokinin as stimulators of increased hunger. The long signal is played by fat-derived hormones, leptin, and insulin, which play a role in the regulation of energy storage and balance.

Table 3 indicated that in its provision as an appetite enhancer, each species of plant was processed in the same way, namely, by smoothing, grating, or thinly slicing, and then boiling and squeezing to take the juice. This way of extraction process was done in the hope that the contained efficacious compounds can be taken entirely. The addition of sugar or honey and salt, which was done to give a better taste for easy drinking. In line with the traditional processing procedure, it was also carried out in this test, which aimed to determine the contents of active compounds in the plants (Table 2).

Based on the information from informants, phytochemical studies and cross-checking of various literature showed that the plants which were commonly used by the Karya Usaha Hamlet are efficacious as a drug for enhancing toddler's appetite, and also have other properties in the health scope. Traditionally, people in other parts of Indonesia utilized kencur rhizomes to treat flu for toddlers, flatulence, and massage in infants, including for postnatal scrubs, powder for sprains, and cracks or fractures (Arum 2012). Not only that, but it also has the potential to overcome coughs and colds (Limananti and Triratnawati 2003), anti-inflammatory (Limananti and Triratnawati 2003; Umar et al. 2011; Shetu et al. 2018), antidiarrhea, cytotoxic (Shetu et al. 2018), analgesic, nematicidal, mosquito repellent, larvicidal, vasorelaxant, 
sedative, antineoplastic, antimicrobial, antioxidant, antiallergic and wound healing properties (Umar et al. 2011; Shetu et al. 2018). The results of previous studies demonstrated that turmeric is advantageous for stomach pain and internal medicine. Turmeric rhizome is also useful for reducing the risk of rheumatic diseases, heart disease, tumors, cancer, Alzheimer's, and other infectious diseases. In addition, it is efficacious to cure diarrhea, ringworm, abdominal pain during menstruation, ulcers, liver, and bloating (Meytia et al. 2013). The ginger rhizome of the plant was reported as an active agent in treating the exhausted body, increasing appetite, and curing typhus and liver disease (Arum 2012). The ginger rhizome is also useful in eliminating unpleasant body odor, overcoming jaundice and ulcers (Meytia et al. 2013), increasing appetite, maintaining endurance, overcoming kidney disease, itching, and eczema, as well as to overcoming flatulence, anti-inflammatory (Limananti and Triratnawati 2003), antioxidant (Adel and Prakash 2010), and endocrinal disorders and tooth pain (Thomas et al. 2020). Fingeroot rhizome is beneficial as antimicrobial, antifungal, antibacterial, antioxidant, and to overcome obesity (Chahyadi et al. 2014). Papaya leaves were reported as ethnomedicine (Aravind et al. 2013; Bamisaye et al. 2013; Vyas et al. 2014; Akhila andVijayalakshmi 2015), it was also claimed as antimalarials, to overcome blood deficiency (Arum 2012), to increase appetite, and as an anti-inflammatory (Limananti and Triratnawati 2003). Temu ireng rhizome was suggested in overcoming fatigue, increasing appetite, recovering stamina after typhus, and post-liver disease (Arum 2012), treating malaria, treating hepatitis (Meytia et al. 2013), overcoming flatulence, intestinal worms, and cough (Limananti and Triratnawati 2003), also as antibacterial (Theanphong et al. 2015) and antimicrobial (Akarchariya et al. 2017).

People in the Karya Usaha Hamlet usually used plants as an appetite enhancer for children under five. Based on the informants, the plants they used were galangal (Kaempferia galanga L.), turmeric (Curcuma domestica L.), Javanese turmeric (Curcuma xanthorrhiza Roxb.), fingerroot (Boesenbergia pandurata (Roxb.) Schlecht), papaya (Carica papaya L.), red ginger (Zingiber officinale Rosc.), and aeruginous turmeric (Curcuma aeruginosa Roxb.). In terms of the usage as an appetite enhancer, the used plant parts were diverse; each species of plant was processed in nearly the same way, namely smoothing, grating, or thinly slicing and then boiling and squeezing to take the juice.

\section{ACKNOWLEDGEMENTS}

Our gratitude is for the entire community of Karya Usaha Hamlet, Kuala Mandor B Sub-district, Kubu Raya District, West Kalimantan Province, Indonesia who have been willing to share their knowledge about the efficacy of plants as an appetite enhancer for toddlers. Our gratitude is also for Dr.rer Nat Rini Muharini for her input and advice in the process of phytochemical extraction and screening, and also for Eko Sri Wahyuni and Titin for their inputs and suggestions in the inventory process of plant species.

\section{REFERENCES}

Adel PRS, Prakash J. 2010. Chemical composition and antioxidant properties of ginger root (Zingiber officinale). J Med Plants Res 4 (24): 2674-2679.

Akhila S, Vijayalakshmi Ng. 2015. Phytochemical Studies on Carica papaya Leaf Juice. Int J Pharm Sci Res 6 (2): 880-883.

Albuquerque UP, Ramos MA, de Lucena RFP, Alencar NL. 2014. Methods and techniques used to collect ethnobiological data. In: Albuquerque UP, Cruz da Cunha LVF, Paiva de Leucena RF, Alves RRN (eds.). Methods and Techniques in Ethnobiology and Ethnoecology. Springer Science and Business Media, New York.

Aravind G, Debjit B, Duraivel S, Harish G. 2013. Traditional and medicinal uses of Carica papaya. J Med Plants Stud 1 (1): 7-15.

Arum GPF, Retnoningsih A, Irsadi A. 2012. Ethnobotany medicinal plants in Keseneng Village, Sumowono Sub-district, Semarang District, Central Java. Unnes J Life Sci 1 (2): 126-132. [Indonesian]

Bamisaye FA, Ajani E O, Minari JB. 2013. Prospects of ethnobotanical uses of pawpaw (Carica papaya). J Med Plant Stud 1 (4): 171-177.

Boquin M, Smith-Simpson S, Donovan SM, Lee SY. 2014. Mealtime behaviors and food consumption of perceived picky and non-picky eaters through home use test. J Food Sci 79 (12): S2523-S2532. DOI: 10.1111/1750-3841.12698.

BPOM RI. 2014. Know the nutritional adequacy rate (RDA) for the Indonesian nation. Info POM 201415 (4): 1-12. [Indonesian]

Brown CL, Schaaf EBV, Cohen GM, Irby MB, Skelton JA. 2016. Association of picky eating and food neophobia with weight: a systematic. Rev Child Obes 12 (4): 247-262.

Cardona CS, Tiemeier H, Van Hoeken D, Tharner A, Jaddoe VW, Hofman A, Verhulst FC, Hoek HW. 2015. Trajectories of picky eating during childhood: a general population study. Int $\mathrm{J}$ Eating Disorders 48 (6): 570-579. DOI: 10.1002/eat.22384

Chahyadi A, Hartati R, Wirasutisna KR, Elfahmi. 2014. Boesenbergia pandurata Roxb., an Indonesian medicinal plant: phytochemistry, biological activity, plant biotechnology. Procedia Chemist 13: 13-37.

Cofnas N. 2019. Is vegetarianism healthy for children? Crit Rev Food Sci Nutr 59 (13): 2052-2060.

Cowbrough K. 2010. Feeding the toddler: 12 months to 3 years-challenges and opportunities. J Family Health Care 2 (2): 49-52

Creswell JW. 1994. Research design: qualitative and quantitative approaches. Sage Publications, London.

Ferreira WS, Alencar NL, Albuquerque UP. 2014. Methods for data collection in medical ethnobiology. In: Albuquerque UP, Cruz da Cunha LVF, Paiva de Leucena RF, Alves RRN (eds.). Methods and Techniques in Ethnobiology and Ethnoecology. Springer Science and Business Media, New York.

Harborne JB. 1987. Phytochemical Methods Guide The Modern Way of Analyzing Plants. Springer Science and Business Media, New York.

Horst KVD, Deming DM, Lesniauskas R, Carr BT, Reidy KC. 2016. Picky eating: Associations with child eating characteristics and food intake. Appetite 103: 286-293.

Hulett JL, Weiss RE, Bwibo NO, Galal OM, Drorbaugh N, Neumann CG. 2014. Animal source foods have a positive impact on the primary school test scores of Kenyan school children in a cluster-randomized, controlled feeding intervention trial. Br J Nutr 111 (5): 875-86. DOI: 10.1017=S0007114513003310.

Iskandar J, Ramlan A, Suryana Y. 2004. Ethnobotany study of the utilization of species of plants as traditional medicines by the Cibunar Community, Rancakalong Sub-district, Sumedang District, West Java. Biotika 2 (1): 22-33. [Indonesian]

Klein DA, Walsh BT. 2004. Eating disorders: clinical features and pathophysiology. Physiol Behav 81: 359-374.

Kumar R, Saikia P. 2020. Wild edible plants of Jharkhand and their utilitarian perspectives. Indian J Tradit Know 19 (2): 237-250.

Ledo S, Seran W. 2019. Diversity of medicinal plants in Baumata Nature Tourism Park and their utilization by local communities in Kupang District, East Nusa Tenggara. J Agribisnis Perikanan 11 (2): 299-310. [Indonesian] 
Limananti AI, Triratnawati A. 2003. The herbal concoction as a cure for lack of appetite in children: a study of ethnomedicine. Makara Kesehatan 7 (1): 11-20. [Indonesian]

Mabel Y, Simbala H, Roni Koneri R. 2016. Identification and utilization of Dani medicinal plants in Jayawijaya District, Papua. J MIPA Unsrat Online 5 (2): 103-107 [Indonesian]

Marandi RR, Britto SJ. 2015. Medicinal properties of edible weeds of crop fields and wild plants eaten by Oraon Tribal of Latehar District, Jharkhand. Intl J Life Sci Pharm Res 5 (2): 9-19.

Melina V, Craig W, Levin S. 2016. Position of the academy of nutrition and dietetics: vegetarian diets. J Acad Nutr Diet 116 (12): 1970-1980. DOI: 10.1016/j.jand.2016.09.025.

Meytia D, Yulianty, Master J. 2013. Inventory of plants used as medicine by the community in Jati Agung Sub-istrict, South Lampung District. National Seminar on Science \& Technology V. Lembaga Penelitian Universitas Lampung, Lampung. [Indonesian]

Muthmainnah B. 2016. Identification of chemical components of papaya leaf extract (Carica papaya L.) originating from Bulupoddo, Sinjai District. J Pharm Sci Herbal Tech 1 (1): 12-18. [Indonesian]

Niranjan A, Prakash D. 2008. Chemical constituents and biological activities of turmeric (Curcuma longa L.)-A review. J Food Sci Technol 45 (2): 109-116.

Noorcahyati. 2012. Tumbuhan Berkhasiat Obat Etnis Asli Kalimantan. Balai Penelitian Teknologi Konservasi Sumber Daya Alam. Badan Litbang Kementrian Kehutanan. Samboja, Samarinda. [Indonesian]

Northstone K, Emmett P. 2013. The associations between feeding difficulties and behaviors and dietary patterns at 2 years of age: the ALSPAC cohort. Maternal Child Nutr 9 (4): 533-542. DOI: 10.1111/j.1740- 8709.2012.00399.x.

Saudah, Viena V, Ernilasari. 2019. Exploration of medicinal plant species based on local wisdom from Pidie District. J Tumbuhan Obat Indonesia 12 (2): 56-67. [Indonesian]

Shetu HJ, Trisha KT, Sikta SA, Anwar R, Rashed SSB, Dash PR. 2018 Pharmacological importance of Kaempferia galanga (Zingiberaceae): A mini-review. Intl J Res Pharm Pharmaceut Sci 3 (3): 32-39.

Silalahi M, Nisyawati. 2018. The ethnobotanical study of edible and medicinal plants in the homegarden of Batak Karo Sub-ethnic in North Sumatera, Indonesia. Biodiversitas 19 (1): 229-238.

Sørensen LB, Møler P, Flint A, Martens M, Raben A. 2003. Effect of sensory perception of foods on appetite and food intake: a review of studies on humans. Intl J Obesity 27: 1152-1166.
Statistics of Kuala Mandor A Village. 2019. [Indonesian]

Thakur S, Tashi N, Singh B, Dutt HC, Singh B. 2020. Ethnobotanical plants used for gastrointestinal ailments by the inhabitants of the Kishtwar plateau in Northwestern Himalaya, India. Indian J Tradit Know 19 (2): 288-298.

Tharner A, Jansen PW, Kiefte-de JJC, Moll HA, van der Ende J, Jaddoe VWV, Hofman A, Tiemeier H, Franco OH. 2014. Toward an operative diagnosis of fussy/picky eating: a latent profile approach in a population-based cohort. Int J Behav Nutr Phys Act 11 (1): 14. DOI: 10.1186/1479-5868-11-14.

Theanphong, Orawan, Withawat M, Chalermpol K. 2015. Chemical constituents and biological activities of essential oil from Curcuma aeruginosa Roxb. rhizome. Bull Health Sci Technol 13 (1): 16.

Thomas VP, Jose J, Mol ST S, Thomas BT. 2020. Ethnobotanical significance of Zingiberales: a case study in the Malaipandaram tribe of Southern Western Ghats of Kerala. Indian J Tradit Know 19 (2): 450-458.

Tjitrosoepomo G. 2009. Dasar-Dasar Taksonomi Tumbuhan (Taksonomi Umum). Gadjah Mada University Press, Yogyakarta. [Indonesian]

Umar MI, Asmawi MZB, Sadikun A, Altaf R, Iqbal MA. 2011. Phytochemistry and medicinal properties of Kaempferia galanga $\mathrm{L}$. (Zingiberaceae) extracts. Afr J Pharm Pharmacol 5 (14): 1638-1647.

Utami NR, Rahayunungsih M, Abdulah M, Haka FH. 2019. Ethnobotany of medicinal plants surrounding communities on Mount Ungaran, Central Java. Pros Sem Nas Masy Biodiv Indon 5 (2): 205-208. [Indonesian]

Van Steenis. 2008. Flora. PT Pradnya Paramita, Jakarta. [Indonesian]

Vyas SJ, Khatri TT, Ram VR, Dave PN, Joshi HS. 2014. Biochemical constituents in a leaf of Carica papaya- ethnomedicinal plant of Kachchh region. Intl Lett Nat Sci 12: 16-20.

Wibisono Y, Azham Z. 2017. Inventory of potential plant types as medicines on the conservation of medicinal plant plots in the Samboja KHDTK, Samboja Sub-district, Kutai Kartanegara District. J Agrifor 16 (1): 125-140 [Indonesian]

Zubair, Suleman SM, Ramadhanil R. 2019. Ethnobotany study of medicinal plants in the Kaili Rai community in Wombo Village, Tanantovea Sub-district, Donggala District, Central Sulawesi. Biocelebes 13 (2): 182-194. [Indonesian] 